\section{Inseminação artificial e anonimato do doador}

\section{Artificial insemination and donor anonymity}

Maria do Carmo Demasi Wanssa 1

1 Programa de Doutoramento em Bioética. Faculdade de Medicina. Universidade do Porto. Alameda Prof. Hernâni Monteiro, 4200319. Porto, Portugal. E-mail: mdwanssa@yahoo.com.br

\begin{abstract}
This article aims to address the issue of the donation of gametes and the anonymity involved in this act of medically-assisted reproduction. It briefly discusses the technical aspects of the donation and selection of gametes and the need for specific legislation on the issue in various countries that have adopted this method, in view of the plurality of different social systems in the world today. The article addresses the legal and ethical issues that are currently being aired in Brazil, and the rulings contained in the Federal Medical Council Resolution 1,358/93, which rules on the conduct of physicians in Brazil and defines, among other things, an act of donation and anonymity, in a way that addresses the question of autonomy. The need for the protection of subjects by way of terms of informed consent or informed refusal, ensuring that necessary information and clarification is made available both to the couple that decide to submit themselves to medically-assisted reproduction and to the donor, who should, in turn, give written assurance of his or her free consent and willingness to cede any rights regarding the gametes to the institution that has taken responsibility for them. All of this, in combination with veracity and confidentiality, are essential if anonymity between donor and recipient is to be upheld. This question of anonymity has been much discussed by scholars from various fields and various parts of the world.
\end{abstract}

Key words Reproduction, Gametes, Insemination, artificial, heterologous

\section{Resumo}

Através desse trabalho, objetiva-se abordar o tema de doação de gametas e do anonimato envolvendo este ato na reprodução medicamente assistida. Analisando rapidamente o caráter técnico da doação e seleção dos gametas e a necessidade de uma legislação especifica sobre o assunto nos diferentes países do mundo que adotaram esse método, diante da pluralidade social existente. Consideram-se os aspectos éticos e legais vigentes no Brasil ditados pela Resolução do Conselho Federal de Medicina $n^{\circ}$ 1.358/93 que determina as condutas dos médicos brasileiros e define, dentre outros aspectos, o da doação e do anonimato, envolvendo o aspecto autonomia. A necessidade de proteção dos sujeitos através do termo de consentimento informado ou de recusa informada, permitindo garantir a informação e esclarecimento necessário ao casal que decide submeter-se aos planos de reprodução medicamente assistida assim como ao doador que, por sua vez, também deve dar garantias escritas quanto à espontaneidade e à alienação dos direitos sobre os gametas à instituição que se torna a responsável por estes. Tudo isso, aliado à veracidade e confidencialidade, compõe os elementos fundamentais para a manutenção do anonimato entre o doador $e$ o receptor. Anonimato este, ainda muito discutido pelos estudiosos de diversas áreas e países.

Palavras-chave Reprodução, Gametas, Inseminação artificial de doador humano 


\section{Introdução}

O desejo de ter um filho sempre existiu desde os tempos remotos nas fantasias do homem e da mulher. Vários são os fatores que impulsionam o homem a reproduzir-se, como o instinto animal da preservação da espécie, o instinto da sobrevivência que tende a proteger a si e a um grupo restrito (família) constituído para ajudá-lo a sobreviver. Também, a pressão social atua no sentido de promover a reprodução, com a sua unidade básica que é a família como responsável pela segurança essencial à sobrevivência do ser humano. $\mathrm{O}$ fato de um casal não conseguir ter filhos era interpretado como um castigo divino desde o início da era cristã e o fato tornara-se indiscutível e irremediável durante quase dois mil anos. 1 A influência de diversas religiões, principalmente da Igreja Católica através do seu dogmatismo, impediram a livre discussão sobre o tema, reforçando a conotação divina à reprodução humana e o conceito da família tradicional constitui a união de um homem e uma mulher e de sua prole, à semelhança da santíssima trindade. $\mathrm{Na}$ sociedade contemporânea, a procriação se liga à ideia de felicidade e de êxito pessoal. Nesse sentido, na maternidade e na paternidade existem fortes traços de identidades individuais, como também, sociais dos indivíduos. Diante disso, a descoberta da infertilidade afeta o equilíbrio do casal e a estrutura familiar, causando um problema de saúde pública. Porém, diante da abordagem médica, há contradições a se analisar, visto a infertilidade não poder se caracterizar primariamente como doença que causa danos físicos ou riscos à saúde ou à vida, apesar de envolver muito sofrimento, podendo ser caracterizada como um agravo à saúde. ${ }^{2}$

O desenvolvimento das técnicas de reprodução medicamente assistida veio trazer a possibilidade real de filhos aos casais com problemas de infertilidade. Pode-se afirmar que esta é a solução na esfera médica, porém, a opção social que consiste na adoção, as iniciativas assistenciais ou mesmo as atitudes de assumir voluntariamente a condição de infertilidade, constituem alternativas que não devem ser esquecidas. ${ }^{3}$

Entretanto, apesar do auxílio que o desenvolvimento das técnicas de reprodução medicamente assistida trouxe no sentido de realização de um dos mais primitivos desejos humanos que é a reprodução, surgiram também preocupações e questionamentos nas variadas esferas como moral, religiosa, jurídica e principalmente as de natureza ética. A reprodução assistida interfere nos desejos individuais e nas normas sociais no campo da reprodução, casamento e família, além de que sua aplicação ultrapassa a terapêutica individual, quando atinge as gerações futuras nos conceitos de início da vida e de valor da vida humana. ${ }^{2}$

A questão de a adoção ser mais correta e justa em um país em desenvolvimento como o Brasil do que a utilização de técnicas de reprodução medicamente assistida, que exige, por parte do casal,o investimento de importantes recursos financeiros além da submissão a riscos à sua própria vida e descendência, deve ser amplamente debatida pela sociedade como um todo. Porém, a autodeterminação dos indivíduos deve ser respeitada, e, hoje, na maioria dos países do mundo, o casal infértil goza de autonomia e liberdade para a escolha da maneira de como resolver seu problema de infertilidade. 4 Porém, a necessidade de questionamento, quanto à legitimidade dessa liberdade e autonomia do consentimento informado fornecido por esses casais, tornase fator primordial diante da grande carga emocional a que estão envolvidos. 1

Contudo, há de se compreender que os países que dominam as técnicas de reprodução medicamente assistida (RMA) têm procurado criar normas e protocolos que estabelecem limites éticos e morais para sua utilização, assim como se tem trabalhado na busca de delimitar o seu campo de apreciação. 4

No Brasil, apesar de não haver ainda legislação que regulamente o assunto, o Conselho Federal de Medicina (CFM) antecipou-se às iniciativas governamentais e, com uma visão mais liberal e atual, em 1992, estabeleceu critérios técnicos e éticos para serem seguidos pelos médicos em exercício da profissão no país que utilizam a técnica, através da Resolução $n^{\circ} 1.358 / 92.5$ Dentre os conflitos éticos abordados na Resolução, observa-se: a necessidade de vínculo matrimonial, a doação de gametas, o número de embriões transferidos, a crio-preservação de gametas e embriões, o diagnóstico genético in vitro e a gravidez de substituição.

O processo de doação de gametas é indicado nos casos em que existe a incapacidade importante ou a falta de gametas de um ou ambos os componentes do casal. No caso da infertilidade feminina, em que se trata da necessidade de ovócitos, diante das dificuldades encontradas relacionadas à técnica de congelamento destes e à hiperestimulação hormonal que se torna imperiosa para o processo de retirada dos mesmos, associada à possibilidade de congelamento já dos embriões excedentes visando novas tentativas de implantação, a quantidade de ovócitos para doação torna-se cada vez mais insuficiente. 6

Por outro lado, o emprego do método de doação de espermatozóide é antigo, tendo o seu primeiro 
relato em 1884 , inclusive com a utilização dos bancos de sêmem que foram criados diante das facilidades apresentadas tanto para a coleta como para o congelamento. Porém, com o surgimento da técnica de Injeção Intracitoplasmática de Espermatozóide (ICSI), esta doação de espermatozóides passou a ser reservada apenas aos casos onde não seria possível a obtenção de espermatozóides através de punção/biópsia. 6

Diante dessas orientações, a intenção desse estudo é abordar as novas tecnologias de reprodução medicamente assistida, no que se refere ao anonimato entre doadores e receptores de gametas masculinos ou femininos, abrangendo seus aspectos técnico, jurídico, psicológico e ético.

\section{A doação de gametas}

A necessidade de um óvulo e de um espermatozóide viáveis é fator fundamental para que ocorra a fecundação. Portanto, neste processo, diante de distúrbios em que há ausência ou insuficiência de qualquer um ou de ambos os componentes necessários, a ciência através do emprego da tecnologia de reprodução medicamente assistida, se propõe a resolver utilizando a chamada reprodução heteróloga. Nesta são utilizados óvulos ou espermatozóides doados, provenientes de outros indivíduos. 4

As indicações médicas para utilização de espermatozóide doado em reprodução medicamente assistida hoje, depois do advento da técnica de injeção intracitoplasmática de espermatozóide, na qual a coleta é feita no próprio interessado através de punção epididimal ou biópsia testicular, ficaram restritas aos casos em que estes procedimentos não são possíveis. ${ }^{6}$ Por sua vez, a doação de ovócitos é indicada na ausência ou disgenesias de ovários ou quando estes não responderem a estímulos hormonais, na incapacidade de fertilização dos ovócitos ou na contra indicação de coleta destas células. ${ }^{2}$

Já a utilização de gametas doados também pode estar associada a riscos de transmissão de doenças genéticas e riscos de doenças autossômicas dominantes ou recessivas por parte dos cônjuges ao concepto, levando os mesmos a esta decisão depois de devidamente esclarecidos. A doação dos gametas, para ser ética, deve proporcionar segurança ao casal e à futura criança. Os gametas devem estar livres de doenças infecciosas (Aids, hepatite) e também de genes causadores de doenças. ${ }^{7}$

No Brasil, as normas éticas adotadas pela Resolução $n^{\circ}$ 1.358/92 do CFM5 exigem um registro permanente das provas diagnósticas a que é submetido o material biológico humano que será transferido aos usuários da reprodução assistida, com a finalidade precípua de evitar a transmissão de doença. Ainda, de acordo com esta Resolução o anonimato do doador para o casal e vice e versa deve ser respeitado. Com a doação, o direito sobre os gametas é transferido para o serviço de captação, entretanto, deve ser mantido o anonimato do doador. $\mathrm{O}$ fato de entre o doador e o casal receptor existir o serviço de captação, facilita o anonimato, até porque permite que haja uma dissociação no espaço e no tempo entre a doação e a inseminação. ${ }^{8}$

A utilização destas células para a criação de préembriões para serem utilizadas em estudos científicos, ainda é um assunto discutível, com muitas restrições, e para isto, os doadores devem especificar o seu aceite. 7

\section{Processo de seleção de doadores}

Para facilitar didaticamente, o processo de seleção de doadores será aqui abordado distintamente, de acordo com o tipo de gameta a ser doado: masculino (espermatozóide) ou feminino (ovócito).

\section{Doação de ovócitos}

A história natural feminina indica que com o passar dos anos o número de ovócitos diminui, com queda brusca a partir dos 35 anos e que se acentua a partir dos 40 anos. Isso ocorre devido ao desequilíbrio entre mitose - processo de divisão celular - e apoptose - morte celular programada - pois, com o tempo, diminui o número das mitoses e aumenta a apoptose. Ainda, com a mudança do comportamento feminino e a inserção da mulher no mercado de trabalho, as aspirações mudaram e a mulher passou a pensar em gestação após os 30 anos de idade, portanto, mais propensa a problemas de infertilidade. 6

Desta forma, a doação de ovócitos tem como objetivo possibilitar mulheres desprovidas de ovócitos ou que não tiverem ovócitos saudáveis a engravidarem e terem filhos. ${ }^{6}$ Porém, em função das dificuldades técnicas, a doação de óvulos foi pouco acessada. Apesar do registro do primeiro bebê nascido com óvulo doado datar de 1993, este fato é recente em comparação à doação de espermatozóide que teve o seu primeiro relato em $1884 .{ }^{9}$ Os ovócitos eram obtidos de pacientes que se submetiam a hiperestimulação num programa de fertilização in vitro e apresentavam grande número de ovócitos pós-punção, como também de mulheres que se submetiam a hiperestimulação somente para doar seus ovócitos, geralmente pacientes que tinham 
alguma dificuldade de engravidar ou parentes de pacientes inférteis.

Entretanto, diante das dificuldades específicas do ponto de vista técnico - a impossibilidade de congelar e disponibilizar óvulos em bancos, associada à possibilidade de congelamento embrionário - o grupo de pacientes que tinha alguma dificuldade de engravidar preferiu submeter seus ovócitos à técnica de fertilização e congelar os embriões excedentes. Então, o número de ovócitos doados passou a não suprir a necessidade, e programas de doação de óvulos com incentivo financeiro surgiram em alguns países como Inglaterra, Dinamarca, Israel, Austrália, Espanha e Grécia. ${ }^{6}$ Em países como o Brasil, em que a doação é um processo anônimo e desprovido de caráter financeiro, existe a proposta de pacientes que precisam de uma reprodução assistida, sem condições financeiras, doarem seus ovócitos excedentes a casais que pagassem seus gastos com as técnicas utilizadas. ${ }^{6}$ Há ainda a possibilidade de parentes de mulheres inférteis " $A$ " doarem seus ovócitos para mulheres inférteis "B", cujos parentes de "B" doarem para as primeiras "A", o que é chamado doação cruzada de ovócitos. ${ }^{9}$

\section{Doação de espermatozóides}

A infertilidade masculina tratada através da utilização do método de doação de gametas é um procedimento antigo, tendo o seu primeiro relato em 1884. 9 Porém, o marco do trabalho da infertilidade masculina grave ocorreu em 1994, com o desenvolvimento da técnica de injeção intracitoplasmática de espermatozóide (ICSI), a qual é utilizada para casais cuja causa da esterilidade é a masculina e que consiste na injeção de um único espermatozóide vivo, com mobilidade, no citoplasma do ovócito.

A partir de então, pacientes portadores de azoospermia por obstrução começaram a ser submetidos à punção epididimal ou biópsia testicular, com o objetivo de buscar espermatozóide à fresco ou como recurso a crio-conservação, até o dia do tratamento da fertilização. Os bancos de sêmen ficaram, então, reservados para os casos onde não se obteria espermatozóides pela punção biópsia. ${ }^{6}$ Essa utilização de espermatozóides testiculares ou epididimais imaturos é feita com sucesso na fecundação e tem deixado a doação heteróloga de espermatozóides relegada apenas aos casos nos quais a referida técnica não se aplica. ${ }^{3}$

\section{Aspectos legais sobre a doação de gametas}

Com o nascimento do primeiro bebê de proveta (Louise Brown) em 1978, na Inglaterra, o mundo viu-se diante de um dilema ético e vários países criaram comissões nacionais governamentais, não para impedir o desenvolvimento do processo científico que envolve essa tecnologia de reprodução, mas sim, para estabelecer limites éticos e morais para sua utilização. 4

No Brasil, a técnica de fertilização in vitro (FIV) teve seu início em 1984, quando nasceu a primeira criança através dessa técnica com transferência embrionária. ${ }^{2}$

Sob a óptica jurídica, não se dispõe de regulamentação legislativa sobre o assunto e o que existe são projetos de lei que aguardam discussão e aprovação legislativa. Guilhem e Prado10 apontam alguns projetos de lei, dentre eles, o Projeto de Lei $\mathrm{n}^{\circ} 3.638 / 93$ (PL1) de autoria do deputado Luiz Moreira, foi o primeiro dos três elaborados que versavam sobre o assunto. Essa proposta tentava reproduzir as normas adotadas pelo CFM em sua Resolução ${ }^{\circ} 1.358 / 92$ que normatiza o assunto.

O Projeto de Lei ${ }^{\circ}$ 2.855/97 (PL2), de autoria do deputado Confúcio Moura, também referenciava a referida Resolução do CFM, mas apresentava avanços em relação ao anterior como definição das técnicas a serem utilizadas e a proibição de utilização das terapias reprodutivas com finalidade de clonagem, seleção de sexo ou qualquer outra característica biológica e eugenia. Além disso, introduzia mecanismos para a proteção da família, enfim, considerava algumas questões morais e sociais da infertilidade humana sempre abordando o tratamento como processo intervencionista, fugindo da possibilidade de uma solução social que é a adoção, considerada relevante para o Ministério Público. 10

A terceira proposta foi elaborada através do Projeto de Lei $\mathrm{n}^{\circ}$ 90/99 (PL3), de autoria do senador Lúcio Alcântara, que se encontra em fase avançada de tramitação, conseguindo desencadear debate social relativo sobre o assunto, no qual diferentes atores expressam suas idéias. As discussões versam sobre a situação social da criança e as implicações sobre a filiação, suscitando a possibilidade de revelação do doador, caso a criança queira saber, após completar dezoito anos. Abordam ainda a proibição do "'útero ou barriga de aluguel" e a proposta de equilibrar a relação comercial e assimétrica entre os indivíduos dispostos a fazer de tudo para ter filhos e os profissionais que são os detentores do poder do conhecimento. 10

As discussões promoveram a elaboração de dois projetos substitutivos. O primeiro substitutivo foi do senador Roberto Requião que substitui o termo consentimento informado, utilizado nos três anteriores, por consentimento livre e esclarecido e 
dispõem sobre a tentativa de resguardar a saúde das mulheres e crianças envolvidas no processo, o limite de três embriões, a prática da redução embrionária como última oportunidade de salvar a vida da gestante. O segundo substitutivo apresentado pelo senador Tião Viana, engloba questões do projeto inicial e do primeiro substitutivo, mas introduz novos tópicos considerados polêmicos, como a transferência de até dois embriões, transferidos a fresco, veda a gestação de substituição. 10

Enfim, na ausência da solução legislativa, a normatização existente é a Resolução do Conselho Federal de Medicina $n^{\circ} 1.358 / 92^{5}$ que estabelece critérios éticos e técnicos a serem seguidos por todos os médicos que atuam no país e utilizam o procedimento.

Foi reconhecida pelo CFM a necessidade de adequação fenotípica:

\footnotetext{
"As clínicas, centros ou serviços que empregam a doação devem manter, de forma permanente, um registro dos dados clínicos de caráter geral, características fenotípicas em amostra de material celular dos doadores". Ainda, registra que: "A escolha dos doadores é de responsabilidade da unidade. Dentro do possível deverá garantir que o doador tenha a maior semelhança fenotípica e imunológica e a máxima possibilidade de compatibilidade com a receptora".
}

E, também deve haver gratuidade na doação, além do anonimato sobre doadores e receptores de gametas e pré-embriões, que em situações especiais ditadas por necessidade médica, as informações clínicas do doador podem ser fornecidas, resguardando-se, sua identidade. 4

Porém, é essencial a firmação de um termo de consentimento informado quando o casal decide submeter-se aos planos reprodutivos discutidos com o médico, pois o casal bem informado e esclarecido estará menos susceptível a imprevistos futuros. O doador deve, por sua vez, dar garantias escritas quanto à espontaneidade do seu ato e à alienação dos direitos sobre os gametas para a instituição responsável pela reprodução medicamente assistida. É um contrato de doação voluntária e de atribuição gratuita, feito com espírito de liberalidade, isto é, com a consciência de estar sendo generoso e não cumprindo um dever. ${ }^{8}$

Com relação à paternidade, nos países onde há leis sobre o assunto, o casal receptor é considerado responsável legal pela criança, não tendo, os doadores nenhum direito sobre os filhos e tampouco os casais poderiam exigir responsabilidades paternas de doadores. ${ }^{7}$ Do mesmo modo, no Brasil, com as normas éticas adotadas pelo CFM, 5 as mesmas que determinam o anonimato do doador para o casal e vice-versa, o casal receptor é o detentor das responsabilidades paternas. ${ }^{7}$ Ainda, o inciso V do artigo 1.597 do novo Código Civil Brasileiro11 presume como concebido na constância do casamento os filhos havidos por inseminação artificial heteróloga, desde que tenha prévia autorização do marido.

As legislações variam diante da pluralidade social existente no mundo contemporâneo e, pode-se citar que a doação de espermatozóide não é permitida para utilização nos procedimentos de FIV em países como Áustria, Egito, Japão, Líbano, Noruega e Suécia, e a doação de óvulos é proibida na Áustria, Egito, Japão, Alemanha, Noruega e Suécia. No Líbano só é permitida se usada pelo próprio marido da doadora para outra esposa. 4 Isto também reflete toda uma gama de conflitos éticos e legais que envolvem este procedimento de reprodução medicamente assistida heteróloga.

\section{Aspectos psicológicos e a doação de gametas}

À luz da psicologia, a inseminação artificial, com recurso à doação de gametas, produz um impacto emocional tanto nos pais quanto nos filhos. Sabe-se que uma gravidez inicia-se muito antes de ter realmente começado.12 A gravidez psicológica é a preparação emocional para os pais e para o novo ser que se pretende conceber, em um processo de vinculação importante ao desenvolvimento da gravidez. A necessidade dos pais se sentirem completos pela extensão de si próprios através do filho, além do papel simbólico do filho em substituir pessoa importante na vida dos pais, traduzem e não esgotam as pressões sociais e outras envolvidas no processo gravídico. Como é sabido, não são os acontecimentos de vida que condicionam nossas emoções, mas a interpretação que se faz deles, e dessa forma, pode-se enfatizar que, se no caso da criança gerada a partir da doação de gametas, tal pensamento não fizer parte da relação, os significados atribuídos poderão resultar numa identificação negativa, levando a sérios problemas relacionais. Ainda, um processo gestacional com forte conotação emocional, desencadeado pela imperiosa necessidade de ter um filho, poderá gerar comportamentos superprotetores nos pais que levarão a perturbações de diversos níveis na criança. ${ }^{1}$

A participação de outros atores no processo de reprodução medicamente assistida interfere no processo de vinculação tão importante para a construção e individualização da pessoa. Não foi identificada diferença entre crianças concebidas 
naturalmente e através da inseminação artificial a respeito de seu desenvolvimento cognitivo, entretanto, devido o fato dessa técnica proporcionar o desenvolvimento de gravidezes múltiplas há opiniões de que pode criar obstáculos ao bom desenvolvimento das crianças. Relacionado ao desenvolvimento sócio- emocional da criança, a discussão gira em torno do anonimato do doador, porém, por se tratar de uma técnica recente, não há estudos que posam dar respostas a essas questões. Portanto, a revelação ou não à criança sobre sua origem é que deve ainda ser discutida, pois crianças nascidas por inseminação artificial com doador poderiam desenvolver problemas de identificação. Há correntes favoráveis ao anonimato que defendem a idéia de que a revelação levaria a criança a desenvolver uma crise de referência entre pai genético e social ou uma neurose social, enquanto que outras insistem que os segredos familiares têm influências nefastas ao desenvolvimento da criança. ${ }^{1}$

\section{Aspectos éticos sobre a doação de gametas}

Existem vários aspectos éticos a serem abordados a respeito da reprodução medicamente assistida heteróloga. As discussões envolvendo o anonimato do doador de gametas remetem a vários aspectos que devem ser analisados do ponto de vista ético. Como favoráveis à manutenção do anonimato, tem-se o fato da minimização da intervenção do terceiro indivíduo na relação conjugal, assim como a perspectiva de doadores disponíveis, que desapareceriam com a inviabilização da técnica de inseminação artificial heteróloga, caso fosse abolido o anonimato. Relacionado ao direito dos filhos ao conhecimento de sua ascendência biológica, as discussões progridem nas defesas do direito à identidade pessoal, enquanto outros reconhecem que esse direito não é absoluto, defendendo que a ruptura do anonimato é medida antiética e ofensiva para os envolvidos no ato de generosidade, benevolência e amor que antecedem este tipo de concepção. ${ }^{13}$

A manutenção do anonimato é considerada de suma importância no sentido de evitarem-se complicações futuras nos aspectos, sobretudo, legais e psicológicos. É controverso o fato das crianças nascidas, através deste processo heterólogo, desconhecerem a sua origem genética, pois, ao tempo que alguns especialistas acreditam que o anonimato dos doadores permite que os pais exerçam uma maior influência de suas identidades sobre os filhos, outros afirmam que geraria uma incompleta percepção de sua identidade à criança, levando a graves repercussões psicológicas. As dúvidas a respeito do ano- nimato do doador persistem mesmo em países onde este não é obrigatório. Os próprios especialistas em reprodução humana divergem sobre o aconselhamento aos pais em revelar à criança a sua origem identificando o doador. A ausência do anonimato, por sua vez, poderia criar situações constrangedoras ou anômalas, onde os doadores poderiam ser um dos filhos do casal estéril, elevando os riscos de problemas emocionais. Situações como complicações obstétricas, nascimento de crianças com incapacidades físicas ou mentais, morte da receptora ou do concepto, poderiam criar para os doadores problemas psicológicos como sentimento de culpa e perda. 4

Os defensores do anonimato do doador justificam que é a única forma de garantir a integridade da família e o desinteresse do doador, e que pessoas poderiam doar seus gametas com o objetivo de serem reconhecidos e terem seus egos narcisistas satisfeitos. Ainda, contra o anonimato estão as correntes de psicólogos e psiquiatras que acreditam na influência nefasta que os segredos familiares provocam no desenvolvimento da criança. ${ }^{1}$

A importância do anonimato do doador deve ainda ser reforçada, levando-se em consideração o direito à confidencialidade à informação genética de acordo com a Declaração dos Direitos Humanos, aprovada na Conferência da Organização das Nações Unidas para Educação, Ciência e Cultura (UNESCO) em 1997, que diz caber ao indivíduo o direito de determinar as circunstâncias em que devem ser reveladas as suas informações genéticas e a quem deve revelar-se. 14

A confidencialidade deve ser vista como expressão daquilo que deve permanecer secreto. Fundamenta-se de duas maneiras distintas, para o sujeito é um direito, ao passo que para terceiros é a expressão de um dever. A pessoa humana como ser autônomo, tem o direito de guardar os seus segredos e também o de revelá-los a quem e quando quiser, tem o direito ao respeito à sua vida privada, à confidencialidade de informações de sua vida pessoal e privada que não queira tornar públicas. 15

Uma análise mais profunda seria necessária em relação ao direito do doador que, como o próprio nome já diz é aquele que, numa atitude de benevolência dá, fornece de maneira espontânea e desinteressada, aquilo que tem e não lhe faz falta, em benefício do outro necessitado, mas que, ao mesmo tempo tem o direito de não querer ter sua identidade revelada, e, principalmente, quando esta revelação envolve outro ser humano gerado ou "produzido" a partir de seu material genético doado. Ora, a sua intenção era a de doação de gameta com finalidade 
de ajudar, beneficiar alguém necessitado, e não a de ser exposto como pai ou mãe biológico de uma nova pessoa que ele, enquanto indivíduo autônomo, não intencionou. Ainda, analisando sob a ótica de terceiros que seria a do dever da confidencialidade, observa-se que os profissionais de saúde envolvidos no processo de reprodução medicamente assistida têm a obrigação de manter esse segredo ou sigilo, visto estas informações serem obtidas através do exercício da prática profissional, de maneira confidencial.

As exceções tanto ao direito como ao dever da confidencialidade podem ser feitas mediante autorização expressa do interessado (doador), a autorização da lei ou ordem expressa do tribunal, uma razão imperativa e justa relacionada com a saúde ou com a segurança do indivíduo ou de terceiro, ou ainda, o respeito a um interesse superior (da coletividade). 15

A doação de gametas com a preservação do anonimato do doador pode fazer suscitar a questão que envolve a consangüinidade nos relacionamentos futuros, através do envolvimento de irmãos consangüíneos gerados por material genético de um mesmo doador anônimo. A ocorrência de casamento futuro de irmãos consangüíneos gerados por um mesmo doador é uma possibilidade, ainda que remota, a ser pensada. O CFM, 5 através da Resolução 1.358/92, utilizou um mecanismo estatístico de controle: "na região de localização da unidade receptora, o registro das gestações evitará que um doador tenha produzido mais que duas gestações, de sexos diferentes, numa área de um milhão de habitantes". Ainda, não é permitido que qualquer integrante da equipe multidisciplinar que prestou serviços na clínica participe como doador nos programas de reprodução assistida. 16

Porém, a ocorrência da consangüinidade levando à produção de gerações futuras geneticamente modificadas ao longo dos tempos, apesar de aplicado mecanismo estatístico de controle, deve ser avaliada pela sociedade e bem esclarecida aos casais receptores das doações.

Deve, também, ser respeitada a autonomia dos sujeitos (receptor e doador) visto que ambos, em seus atos tanto de receber como de doar, têm o direito de ter suas autonomias preservadas de acordo com as suas vontades. Ora, analisando o termo autonomia como autogoverno, direito de liberdade, privacidade, escolha individual, liberdade da vontade, 17 vislumbram-se receptores querendo, desesperadamente, serem pais e mães e doadores que, numa atitude de desprendimento, oferecem seus gametas, sem nenhuma intenção de assumir uma possível paternidade, mas sim de propiciar aos receptores a oportunidade e alegria de realização de seus sonhos esperados.

Garantindo esse processo de autonomia, o consentimento informado deve ser visto como uma autorização autônoma dada por indivíduos autorizando certa intervenção médica ou envolvimento em pesquisa. 17 Neste caso específico, envolvendo reprodução medicamente assistida com doação de gametas, é imprescindível que toda a informação acerca do processo seja revelada ao casal receptor, esclarecida e entendida sobre todos os aspectos envolvidos, sejam técnicos, éticos, legais, psicológicos ou sociais, para que, com competência, seriedade e voluntariedade possam os sujeitos, realizar a expressão do consentimento informado, livre e esclarecido. O desespero e a ansiedade de um casal em ter um filho podem ser vistos como situações de vulnerabilidade, que deixa os indivíduos propensos às tentativas de persuasão racional, sendo influenciado de forma irracional. Assim, o termo de consentimento informado livre e esclarecido deve envolver muito mais que um termo assinado, é necessário a revelação das informações envolvidas no mais amplo sentido possível diante da recomendação do plano proposto e o entendimento destes. Conforme a capacidade de entender e decidir e com a sua voluntariedade, os sujeitos tomarão suas decisões a favor do plano, autorizando através da assinatura do termo, ou decidindo em desfavor, diante do entendimento conseguido e, ainda, de sua voluntariedade. 17

A vulnerabilidade dos sujeitos face à biotecnologia reprodutiva também deve ser considerada. As pessoas envolvidas, além de apresentarem um agravo à saúde, a sensação de impotência em criar uma nova família através da união do casal, predispondo-os à vulnerabilidade, contam, ainda, com a implicação de, na decisão e no consentimento, estarem envolvidos dois sujeitos de sexos diferentes. A continuidade das relações colocadas em cheque pela dificuldade reprodutiva pode influenciar diferenciadamente homens e mulheres em seus processos decisórios. ${ }^{2}$

\section{Considerações finais}

Considerar que o avanço tecnológico conseguido através das técnicas de reprodução medicamente assistida foi estrondoso é indiscutível. A necessidade de criação de normatizações e regulamentações estabelecendo limites deve ser discutida de acordo com as regras sociais existentes nos diferentes países onde as técnicas são aplicadas. A intervenção na 
reprodução humana através da tecnologia é ética e moralmente admissível, porém, deve respeitar os valores fundamentais do ser humano como a dignidade, a autonomia de decisão, o direito à confidencialidade, dentre outros como a família, os valores da reprodução, a licitude dos meios e dos fins, além da garantia de utilização da técnica em benefício da humanidade. 4

Entretanto, apesar do auxílio que o desenvolvimento das técnicas de reprodução medicamente assistida trouxe no sentido de realização de um dos mais primitivos desejos humanos que é a reprodução, as preocupações e questionamentos surgidos nas variadas esferas como moral, religiosa, jurídica e principalmente as de natureza ética, vem desorganizar, ainda mais, as sociedades subdesenvolvidas. A reprodução assistida interfere nos desejos individuais e nas normas sociais no campo da reprodução, casamento e família, além de que sua aplicação ultrapassa a terapêutica individual, quando atinge as gerações futuras nos conceitos de início da vida e de valor da vida humana. 2

A possibilidade real de filhos aos casais com problemas de infertilidade é a solução apresentada pela biotecnologia reprodutiva, na esfera médica, porém, a opção social que consiste na adoção, as iniciativas assistenciais ou mesmo as atitudes de assumir voluntariamente a condição de infertilidade, não devem ser esquecidas. ${ }^{3}$

Aspecto relevante que deve ser discutido à luz da bioética está relacionado à análise sob a ótica da justiça distributiva. Refere-se ao direito que todos, indistintamente, têm diante das propostas de reprodução medicamente assistida, o que não é possível em um país como o Brasil, onde as verbas destinadas à saúde são sempre insuficientes diante da pobreza da população, aliada à malversação das verbas públicas, o que vem conferir a poucos, o direito aos filhos utilizando as novas tecnologias a altos custos. Aliados ao problema social crescente nos países subdesenvolvidos ou em fase de desenvolvimento, onde menores são abandonados à própria sorte, permitindo crescer o desequilíbrio social, com o aumento da miséria e da criminalidade, a perspectiva das soluções sociais de adoção se tornam prioritárias em relação àquelas biotecnológicas. Políticas sérias de incentivo e facilitação ao processo de adoção em países subdesenvolvidos seriam muito mais justas e resolveriam problemas sociais já existentes. Ao contrário, a adoção de políticas de incentivo à reprodução medicamente assistida, remeteriam à criação de novos e sérios problemas de ordem bioética, clamando por novas soluções, diante de uma sociedade pobre e desorganizada do ponto de vista social.

Há, portanto, necessidade de se considerar todos os fatores de modo global e de acordo com as pluralidades sociais existentes em cada país, para que, através de uma discussão ampla, envolvendo diferentes expoentes da sociedade, seja possível chegarse a um denominador comum, decisivo da melhor atitude e das normatizações pertinentes àquela sociedade naquele momento.

\section{Referências}

1. Ricou M. Inseminação artificial com recurso a doação de gametas: implicações psicológicas. In: Nunes R, Melo H, editores. Genética e reprodução humana. Coimbra: Gráfica Coimbra Ltda.; 2000. p. 133-57.

2. Corrêa MCDV. Ética e reprodução assistida: a medicalização do desejo de ter filhos. Rev Bioética. 2001; 9: 7182.

3. Sá Figueiredo HMV. A procriação medicamente assistida e as gerações futuras. Coimbra: Gráfica Coimbra Ltda.; 2005.

4. Pedrosa Neto AH, Franco Júnior JG. Reprodução assistida. In: Costa SIF, Oselka G, Garrafa V, editores. Iniciação à Bioética. Brasília: Conselho Federal de Medicina; 1998. p. 111-24.

5. Brasil. Conselho Federal de Medicina. Resolução N. ${ }^{\circ}$ 1358, de 11 de Novembro de 1992. Adota normas éticas para a utilização das técnicas de reprodução humana assistida. Diário Oficial da União [DOU], p.16053, 19 nov 1992. Seção 1. Brasília, DF.

6. Schefer BB, Schefer RFCB. Gameta: unidade básica em reprodução humana. J. Bras. Med. 2001; 81: 54-7.

7. Castellotti DS, Motta ELA, Salzo I, Serafini PC, Gollop TR. Reflexões éticas em reprodução assistida (parte I). Femina. 1998; 26: 701-7.

8. Melo HP. Problemas jurídicos suscitados pela inseminação artificial com recurso a doador de gametas. In: Nunes R, Melo H, editores. Genética e reprodução humana. Coimbra: Gráfica Coimbra Ltda.; 2000. p. 159-251.

9. Caetano JPJ, Camargos BM. Doação cruzada de oócitos: relato de caso. J Bras Ginecol. 1996; 106: 449-51.

10. Guilhem D, Prado MM. Bioética, legislação e tecnologias reprodutivas. Rev. Bioética. 2001; 9: 113-26.

11. Brasil. Lei $\mathrm{n}^{\circ} 10.406$, de 10 de janeiro de 2002. Novo Código Civil Brasileiro. Diário Oficial da União [DOU], 11 jan 2002. Brasília, DF.

12. Biscaia J, Sá E. A Gravidez no Pensamento das Mães. In: Sá E, editor. A maternidade e o bebê. Lisboa: Fim de Século Edições; 1997. p. 41-50. 
13. Archer L. Procriação Medicamente Assistida - evolução e pensamento ético de 1986 a 1999. In: Nunes R, Melo H, editores. Genética e reprodução humana. Coimbra: Gráfica Coimbra Ltda.; 2000. p. 27-31.

14. Bergel SD. Bioética, genética y derechos humanos: la declaracion de la UNESCO. Rev Bioética. 1999; 7: 165-78.

15. Durand G. Introdução geral à bioética-história, conceitos e instrumentos. São Paulo: Ed. Loyola; 2003.

Recebido em 20 de maio de 2010

Versão final apresentada em 5 de julho de 2010

Aprovado em 2 de agosto de 2010
16. Espindola JS, Contribuição jurídica para a legislação sobre fertilização humana assistida. Rev Bioética. 2003; 11: 91 108.

17. Beauchamp TL, Childress JF. Princípios de ética biomédica. São Paulo: Ed. Loyola; 2002. 